\title{
Geopolitical ecology of solar geoengineering: from a 'logic of multilateralism' to logics of militarization
}

\author{
Kevin Surprise ${ }^{1}$ \\ Mount Holyoke College, USA
}

\begin{abstract}
Solar geoengineering technologies intended to slow climate change by injecting sulfate aerosols into the stratosphere are gaining traction in climate policy. Solar geoengineering is considered "fast, cheap, and imperfect" in that it could rapidly reduce planetary temperatures with low cost technology, but potentially generate catastrophic consequences for climate, weather, and biodiversity. Governance has therefore been central to solar geoengineering debates, particularly the question of unilateral deployment, whereby a state or group of states could deploy the technology against the wishes of the international community. In this context, recent, influential scenarios posit that - given technological and political complexities - solar geoengineering deployment will likely be guided by a "logic of multilateralism." I challenge this assertion by arguing that solar geoengineering is defined by equally compelling 'logics of militarization.' I detail recent involvement in solar geoengineering development on the part of U.S. defense, intelligence, and foreign policy institutions, geoengineering scenarios that adopt militarized logics and expertise, and Realist international relations theories that undergird leading governance scenarios. I then demonstrate that the U.S. military has a strategic interest in solar geoengineering, as U.S. hegemony is predicated on expanding fossil fuels, but the military deems climate change a threat to national security. The unique spatio-temporal qualities of solar geoengineering can bridge the gap between these contradictory positions. In examining the militarization of solar geoengineering, I aim to ground recent conceptions of "planetary sovereignty" in the emergent field of "geopolitical ecology" through the latter's more granular approach to the world-making powers of key geopolitical-ecological actors.
\end{abstract}

Key Words: solar geoengineering, geopolitical ecology, militarization, U.S. hegemony, climate intervention

\section{Résumé}

Les technologies de géo-ingénierie solaire destinées à ralentir le changement climatique en injectant des aérosols sulfatés dans la stratosphère retiennent de plus en plus l'attention des décideurs climatiques. La géo-ingénierie solaire est considérée comme "rapide, bon marché et imparfaite". Il pourrait réduire rapidement les températures planétaires grâce à une technologie à faible coût, mais pourrait générer des conséquences catastrophiques pour le climat, la météo et la biodiversité. La gouvernance a donc été au cœur des débats sur la géo-ingénierie solaire, en particulier la question du déploiement unilatéral, par lequel un État ou un groupe d'États pourrait déployer la technologie contre la volonté de la communauté internationale. Dans ce contexte, des scénarios récents et influents postulent que, compte tenu des complexités technologiques et politiques, le déploiement de la géo-ingénierie solaire sera probablement guidé par une "logique de multilatéralisme". Je conteste cette affirmation, soutenant que la géo-ingénierie solaire est définie par des «logiques de militarisation» tout aussi convaincantes. Je détaille l'implication récente dans le développement de la géo-ingénierie solaire de la part des institutions américaines concernées par la défense, le renseignement militaire et la politique étrangère. J'aborde également des scénarios de géoingénierie qui adoptent une logique et une expertise militarisées, ainsi que des théories de relations

${ }^{1}$ Dr. Kevin Surprise is a Visiting Lecturer in Environmental Studies at Mount Holyoke College, 50 College Street, South Hadley, MA 01075, USA. Email: ksurpris "at" mtholyoke.edu. Acknowledgements: Thank you to Simon Batterbury for editorial guidance, and to Patrick Bigger, Benjamin Neimark, and an anonymous reviewer for helpful comments on earlier drafts of this article. 
internationales réalistes qui soutiennent des scénarios de gouvernance. Je démontre ensuite que l'armée américaine a un intérêt stratégique dans la géo-ingénierie solaire, car l'hégémonie américaine est fondée sur l'expansion des combustibles fossiles, mais l'armée considère que le changement climatique constitue une menace pour la sécurité nationale. Les qualités spatio-temporelles uniques de la géo-ingénierie solaire peuvent combler le fossé entre ces positions contradictoires. En examinant la militarisation de la géoingénierie solaire, je vise à ancrer les conceptions récentes de la "souveraineté planétaire" dans le domaine émergent de "l'écologie géopolitique". Ce dernier a une approche plus granulaire des principaux acteurs géopolitiques et écologiques et de leurs pouvoirs.

Mots clés: géo-ingénierie solaire, écologie géopolitique, militarisation, hégémonie américaine, intervention climatique

\section{Resumen}

Las tecnologías de geoingeniería solar dirigidas a desacelerar el cambio climático introduciendo aerosoles de sulfato a la estratósfera, están tomando fuerza en las políticas climáticas. La geoingeniería solar es considerada "rápida, económica e imperfecta" por reducir rápidamente la temperatura del planeta con tecnología de bajo costo, aunque potencialmente puede generar consecuencias catastróficas para el clima, el ambiente y la biodiversidad. Por consiguiente, la gobernanza ha sido central para los debates en torno a la geoingeniería solar, especialmente en su despliegue unilateral, a través del cual, un estado o grupo de estados puede implantar la tecnología contra de la voluntad de la comunidad internacional. En este contexto, recientes e importantes situaciones plantean que -dadas las complejidades tecnológicas y políticas- el despliegue de geoingeniería solar probablemente sea guiado por una "lógica de multilateralismo". Yo cuestiono esta aseveración al discutir que la geoingeniería solar está definida por "lógicas de militarización” igualmente convincentes. Aquí, abordo a detalle el reciente involucramiento en el desarrollo de geoingeniería solar por parte de la defensa, inteligencia, instituciones de política exterior de Estados Unidos, contextos de geoingeniería que adoptan lógicas militarizadas y experticia, y teorías de relaciones internacionales Realistas, las cuales, apuntalan coyunturas importantes de gobernanza. Posteriormente expongo que las fuerzas armadas de Estados Unidos tienen un interés estratégico en geoingeniería solar, ya que mientras la hegemonía estadounidense está basada en los combustibles fósiles, el ejército considera el cambio climático como una amenaza a la seguridad nacional. Las características espacio-temporales únicas de la geoingeniería solar, pueden superar la brecha entre estas posiciones que se contraponen. Al analizar la militarización de la geoingeniería solar, me propongo aclarar ideas recientes de "soberanía planetaria" en el incipiente campo de la "ecología geopolítica" a través del acercamiento granular militar hacia los poderes transformadores mundiales de actores geopolíticos y ecológicos clave.

Palabras clave: geoingeniería solar, militarización, ecología geopolítica, hegemonía de Estados Unidos, imperialismo, unilateralismo

\section{Introduction}

Although not made entirely explicit ... 'unilateral' [geoengineering] appears to mean any deployment not conducted by or coordinated with the United States.

Jeremy Baskin, 2019

At the 2019 United Nations Environment Assembly, Switzerland advanced a resolution that would require the UN Environment Program to draft guidance for UN member countries on how move forward with geoengineering research. The resolution was backed by nine other countries, but ultimately blocked by an alliance of Brazil, Saudi Arabia, and the United States (Chemnick 2019). This incident highlights two salient features of geoengineering governance: interest in the technology is growing among leading nationstates and international institutions, and its development will be subject to the machinations of geopolitics in an increasingly illiberal world order. Institutionalized governance has preoccupied much of the geoengineering literature, while geopolitical analyses remain limited.

Solar geoengineering augurs the capacity to quickly cool the planet by modifying Earth's albedo. The leading approach - Stratospheric Aerosol Injection (SAI) - would entail continually spraying megatons of 
sulfate aerosols (e.g. sulfur dioxide) into the lower stratosphere to reflect a percentage of solar radiation back to space. SAI is often described as "fast, cheap, and imperfect": it could rapidly reduce global average temperature, and would likely cost tens of billions of dollars compared to the tens of trillions necessary for rapid, economy-wide energy transitions, but only address the warming symptoms of climate change (Keith et al. 2010). SAI must, therefore, be paired with significant emissions cuts, particularly as perpetual deployment in the midst of rising greenhouse gases could prove disastrous: heat would bottle up in the atmosphere rendering any abrupt termination of SAI a trigger for rapid warming (McKinnon 2019; Parker and Irvine 2018). Hence governance of this potentially inexpensive, technically feasible technology with planetary reach that could produce catastrophic outcomes has been the foremost aspect of solar geoengineering debates.

Of particular concern is the potential for unilateral deployment: that a state or group of states could deploy SAI against the wishes of the international community (Keith 2013; Rabitz 2016; Reynolds 2019; Victor et al. 2009). To prevent such a scenario, there is widespread agreement that governance mechanisms must be in place prior to any form of large-scale experimentation or deployment (Chhetri 2018), and growing recognition that scenarios for deployment significantly shape the design of SAI governance architecture (Keith and MacMartin 2015; Low 2017; McClaren 2018; Sugiyama et al. 2018; Talberg et al. 2018). Leading SAI research institutions are therefore producing increasingly detailed models and scenarios of SAI deployment, many of which aver that deployment should be limited in scope and governed cooperatively by states working through international institutions to minimize climate vulnerabilities and enhance global welfare (Irvine et al. 2019; Parker et al. 2018; Smith and Wagner 2018; Stavins et al. 2018). This vision of governance acknowledges the potential for conflict, but is guided by a belief that the technological and political requirements of SAI deployment render it "ruled ... by a logic of multilateralism" (Horton 2011, my emphasis).

I challenge this sanguine "logic of multilateralism" by demonstrating that SAI is equally likely to be ruled by "logics of militarization." This argument is elaborated in four sections. First, I outline the ways in which U.S. defense, intelligence, and foreign policy institutions have been involved in solar geoengineering development over the past two-plus decades, and detail two influential scenarios for SAI deployment that adopt militarized logics. Second, I explore theoretical axioms that underpin these scenarios to demonstrate that they are severely constrained by Realist International Relations (IR) theory, and turn to scenarios that situate SAI in the imperial geopolitics of global capitalism (Arrighi's [2010] "systemic cycles of accumulation" and Wainwright and Mann's [2018] "planetary sovereignty"). Third, I expand on these scenarios to argue that strategies for the maintenance of declining U.S. hegemony are increasingly reliant on the underlying, material substrates of U.S. geopolitical power: military dominance, the dollar as the global reserve currency, and control of fossil fuel energy (particularly oil). These phenomena are not reducible to one another, but neither can they be easily divorced. At the same time as U.S. power is predicated on the expansion of fossil fuels, the U.S. military considers climate change a "threat multiplier." SAI's speed and planetary scope offer singularly unique strategic qualities that can bridge the contradictory goals of fossil fuel expansion and climate stability. In the final section, I link emerging military conceptions of climate security with U.S. "command of the commons" and the relationship between U.S. hegemony, climate "intervention", and international law to argue that the U.S. is the only actor capable of unilateral deployment for the foreseeable future.

In connecting these processes, this article makes two interventions. First, in the geoengineering governance field, it demonstrates that reliance on a narrow set of theoretical approaches results in a fundamental elision of both the militarization of the technology to date, and the potential for strategic (rather than tactical or weaponized) deployment of SAI on the part of the U.S. military. Second, it links conceptions of "planetary sovereignty" (Wainwright and Mann 2018) with the emerging framework of "geopolitical ecology" (Bigger and Neimark 2017). ${ }^{2}$ Geopolitical ecology combines "political ecology's careful attention to multi-scale environmental politics and the discursive-material co-constitution of global institutional

${ }^{2}$ See Loftus (2018) for a discussion of these frameworks in political ecology. Loftus notes their emergence and potential for generative scholarship, but does not link them or read one through the other. 
politics ... to gain a deeper understanding of the role of large geopolitical institutions, like the U.S. military, in environmental change" (Bigger and Neimark 2017: 14; see also Belcher et al. 2020). This framework coalesces scholarship that analyzes militarization in energy, conservation, and climate change, with conservation projects utilized to justify military expansion (Büscher and Fletcher 2018; Duffy 2016; Lundstrom 2014; Marijnen and Verweijen 2016), and climate policy increasingly influenced by military logics, discourse, and strategy (Chaturvedi and Doyle 2015; Dalby 2013a; 2013b; Foster et al. 2019; Gilbert 2012; O'Lear 2018; O'Lear and Dalby 2015).

Wainwright and Mann's generative yet abstract conception of planetary sovereignty rooted in the declaration of emergency can be modulated by geopolitical ecology's more granular approach to the worldmaking power of geopolitical actors. I argue that the capacity for planetary-scale intervention in the climate crisis is neither driven by a "logic of multilateralism" nor dependent on a new form of sovereign power. Rather, this capacity is consonant with the strategic logic of current U.S. strategy, and immanent to alreadyexisting imperial power under international law.

\section{Climate intervention: the militarization of solar geoengineering}

Debates over the geopolitics of SAI tend to revolve around broad conceptions of "security" (Cairns and Nightingale 2014; Chalecki and Ferrari 2018; Corry 2017; Dalby 2015; Horton and Reynolds 2016; Maas and Sheffran 2013). Yet, climate politics - and geoengineering - are not merely being "securitized", but increasingly militarized (Gilbert 2012; Roberts 2018). Bernazzoli and Flint (2009) draw on Agamben's (2005) formulation of modern rule as a "generalization of the paradigm of security as the normal form of government" to distinguish 'securitization' from 'militarization,' arguing that the latter too rigidly separates military and civilian spheres while the former analyzes the ways in which they are increasingly fused together. Yet, subsuming militarization into the general category of security can elide important distinctions concerning explicit military influence in powerful socio-technical assemblages like solar geoengineering, in that their development and rationale come to be defined by military logics and the preparation for violence or conflict (Lutz 2002, 2004). SAI is being militarized via involvement of the Department of Defense (DoD) and cognate institutions ${ }^{3}$ in its development, scenarios for deployment reliant on military logics and technologies, and the increasingly prevalent language of "climate intervention" subject to the rules of war (Chalecki and Ferrari 2018; National Research Council 2015). ${ }^{4}$

References to militaries and SAI tend focus on past legacies of Cold War-inspired weather weaponization (Buck 2012; Fleming 2010; Hamilton 2013; Keith 2000; Victor et al. 2009; though see Nightingale and Cairns (2014), and Baskin's (2019) genealogy connecting this lineage to the present ${ }^{5}$ ). This literature is largely inattentive to the ways in which the technology continues to be militarized. For example,

\footnotetext{
3 This includes U.S. intelligence agencies, defense-oriented think tanks and university institutes, and defense contractors. Although not explicitly "military", they are all intertwined with the Pentagon and serve to advance U.S. imperialism.

${ }^{4}$ Perhaps a middle ground analysis between broad conceptions of security and more focused analyses of militarization can be found in STS literature which argues that SAI is likely to augur highly concentrated and potentially authoritarian governance structures (see Baskin 2019; Hamilton 2013; Hulme 2014; Markusson et al. 2014; Szerszynski et al. 2013). Thank you to a reviewer for pointing out this option.

${ }^{5}$ Baskin (2019) provides an excellent review and analysis of the solar geoengineering field, key aspects of which are aligned with my own approach. In particular, his argument that solar geoengineering technologies are embedded within systems of power that render them in service the capitalist status quo, advanced through an "imperial imaginary" that gains legitimacy via appeals to humanitarianism in conditions of emergency (see Surprise 2018, 2019 for elaboration on these themes). Baskin and I differ is in our conception of imperialism. Baskin's STS approach couches imperialism as a dominant yet competing "imaginary" in the geoengineering field more or less consciously advanced by geoengineering researchers. My approach understands imperialism as a structural necessity of capitalism in which solar geoengineering technologies could be strategically enrolled (regardless of the intentions of researchers). This difference recalls the Hobson-Lenin debate, in which the latter challenged the former's conception of imperialism as a policy choice rather than a structural imperative of global capitalism.
} 
a recent, authoritative survey of governance (Reynolds 2019) offers only a limited discussion of the relationship between militaries and SAI. The clearest statement reads as follows:

[T] he military's role in solar geoengineering should ideally be restricted ... the involvement of the military - particularly in hegemonic states - could undermine international confidence and trust. At the same time, militaries possess useful equipment and knowledge regarding complex logistical operations at high altitudes and at sea. A complete rejection of any military role might be harmful. One possible boundary would be to allow military institutions to serve as secondary partners ... Nevertheless, given governance's decentralized nature at this state, it is unclear how such limitations could be adopted and effective. (Reynolds 2019: 207, my emphasis)

Military involvement in solar geoengineering should be restricted as it could undermine trust, yet militaries have necessary equipment and expertise such that blocking their involvement could prove harmful. Thus, a boundary should be established that allows yet limits military involvement, but no mechanisms exist to create and effectively enforce such a boundary. This evasive statement elides the fact that some leading outposts of SAI research are already entwined with U.S. military and intelligence institutions, and is symptomatic of a governance literature dominated by IR theories that view the U.S. as merely one powerful player among many in an anarchic international system, rather than an imperial hegemon. I take each in turn.

\section{Defense, intelligence, and foreign policy influence in SAI development}

Contemporary interest in SAI began with articles published by Edward Teller and Lowell Wood, both long affiliated with the Lawrence Livermore National Laboratory and the conservative Hoover Institute (Teller, Wood and Hyde 1996, 2002). Teller, a nuclear physicist involved with the Manhattan Project and hydrogen bomb served - with Wood as his protégé - as science advisor to the Reagan Administration on multiple weapons projects, including the Strategic Defense Initiative (i.e. 'Star Wars'). Teller and Wood's work inspired Ken Caldeira, an atmospheric scientist at Livermore from 1993 - 2005, to undertake research on solar geoengineering (Govindasamy and Caldeira 2000), and Caldeira remains a prominent figure in SAI research (e.g. climate advisor to Bill Gates - the leading funder of SAI research; Necheles et al. 2018).

In 2001, the Bush Administration's Climate Change Technology program convened a meeting on "Response options to rapid or severe climate change", organized by Livermore alum Mike MacCraken. Details of the meeting are sparse, but David Keith (a major figure in the geoengineering field) was in attendance, remarking: "If they had broadcast that meeting live to people in Europe, there would have been riots ... here were the bomb guys from Livermore talking about stuff that strikes most greens as being completely wrong and off-the-wall" (Popular Science 2005). Following these discussions, the Department of Defense commissioned a report entitled An abrupt climate change scenario and its implications for United States national security. The report lists recommendations to the U.S. defense community that include the exploration of "geoengineering options that control the climate", noting that they must be "studied carefully as they have the potential to exacerbate conflict among nations" (Schwartz and Randall 2003: 22).

In 2006 Caldeira, Keith, and Wood participated in a NASA-sponsored solar geoengineering conference (Lane et al. 2007), and in 2008 the Council on Foreign Relations (CFR) - a bastion of the U.S. foreign policy establishment - hosted a workshop on unilateral geoengineering. Ricke et al. (2008) prepared a briefing for the workshop later published in CFR's flagship journal Foreign Affairs (Victor et al. 2009). Although NASA and CFR are not explicitly military institutions, the lines between establishment foreign policy think tanks, aerospace, and national defense have long been indistinct (Edwards 1997). Following these events, the Defense Advanced Research Projects Agency (DARPA) hosted an unpublicized meeting on SAI (Kintisch 2009), and Novim - created in the image of the JASON Group, a scientific advisory body to DARPA - convened a study to examine use of SAI in emergencies (Blackstock et al. 2009). The Novim 
workshop and subsequent report included Keith and Calderia as co-authors, and was led by Steve Koonin, who served as director of the JASON Group in the early 2000s. ${ }^{6}$

A number of instances followed in 2010 - 2011. The House Committee on Science and Technology held a hearing on geoengineering where military and security concerns were prominent. The Aerospace Corporation, a federally funded research and development center that works closely with the U.S. Air Force, conducted a study into space-based methods for detecting sulfuric aerosols in the stratosphere (so as to determine whether or not SAI has been deployed) (Smith et al. 2010). The RAND Corporation, a leading defense think tank, analyzed solar geoengineering scenarios to inform U.S. policymakers on governance and security (Lempert and Prosnitz 2011), ${ }^{7}$ The Bipartisan Policy Center published a geoengineering report that included authors from Livermore, Boeing, and the State Department (BPC 2011; Baskin 2019), and Alan Robock, an atmospheric scientist critical of SAI, reports getting a call from the Central Intelligence Agency (CIA) asking whether intelligence agencies would be able to detect deployment (Robock 2015).

The CIA put formal resources into exploring solar geoengineering in 2013, initiating and funding a U.S. National Academies study into the scientific, technical, and political aspects of "climate intervention" (Liebelson and Mooney 2013; National Research Council 2015). Military interest continued in 2015 via The Center for Naval Analysis running a series of "climate war games" in Delhi, India with former diplomats and military officers from multiple countries. Solar geoengineering was included as a tactic in these games, and results demonstrated that few peaceful mechanisms exist to stop determined unilateral deployment (Schkoda 2016). In 2016, the National Intelligence Council released a report on climate change and national security that highlighted security concerns of unilateral solar geoengineering. In the same year John Brennan - then director of the CIA - gave a speech to CFR noting his interest in SAI to prevent the security threats of climate change (with this interest presumably extending to the wider Agency, as the CIA has been exploring SAI since at least 2011; Brennan 2016).

The following year, the Pacific Northwest National Laboratory (PNNL) and the National Center for Atmospheric Research (NCAR) published research funded by DARPA exploring multiple latitude points for SAI dispersal and the design of algorithmic feedback mechanisms to monitor and adjust active deployment (Kravitz et al. 2017; Tilmes et al. 2017). DARPA also had a presence at the exclusive 2017 Gordon Research Conference on Solar Geoengineering. Shortly thereafter, Strategic Studies Quarterly, "the peer reviewed strategic journal of the United States Air Force", published an article examining geoengineering deployment through "just war theory" (Chalecki and Ferarri 2018). In 2019 the House Intelligence Committee held a hearing on the national security implications of climate change where Peter Kiemel, Counselor for the National Intelligence Council, provided testimony noting potential geopolitical tensions of SAI deployment, and the U.S. Army War College released a report on climate security that included discussions of solar geoengineering (Brosig et al. 2019).

Finally, the Harvard Solar Geoengineering Research Program (HSGRP) - the leading center of SAI research in the world - is housed in the Harvard University Center for the Environment, with direct connections (via personnel and funding) to two other Harvard centers: the Weatherhead Center for International Affairs, and the Belfer Center for Science and International Affairs. Both Weatherhead and Belfer have deep, longstanding ties to the defense and intelligence community. As Golden notes, they "swarm with former intelligence brass" (Golden 2017: 214; see also Surprise 2019; Trumpbour 1989). For example, former Belfer Center Director, Graham Allison, served as an Assistant Secretary of Defense and advisor to the CIA, and was replaced as Director by former Secretary of Defense Ashton Carter in 2017. Carter is now formally involved in solar geoengineering discussions at Harvard (Burns and Keith 2018; Keith 2019). HSGRP is also currently developing the first in situ SAI field-experiment - the Stratospheric

\footnotetext{
${ }^{6}$ Koonin also served as Vice President and Chief Scientist at British Petroleum (2005-2009) during the time of this study, and later as an undersecretary at the Department of Energy in Obama Administration, leaving in 2011 to take a position at the Institute for Defense Analysis.

${ }^{7}$ Lempert is at RAND while Prosnitz is Associate Senior Fellow at the Center for Global Security Research at Lawrence Livermore National Laboratory.
} 
Controlled Perturbation Experiment (ScoPEx, see Dykema et al. 2014) - in partnership with Raven Aerostar, a long-time DoD contractor with specializations ranging from border security to surveillance, and recent, multi-million dollar contracts with the U.S. Navy and Air Force.

\section{Deployment scenarios, militarized logic, and expertise}

The influence of this creeping militarization is evidenced by two recent scenarios produced by HSGRP and affiliates. First, Parker et al. (2018) explore the possibility of "counter-geoengineering" (CG) mechanisms to deter unilateral deployment. They argue that international climate policy is defined by the so-called "free rider" effect, with states lacking incentives to mitigate carbon emissions, whereas SAI is defined by "free driver", unilateral properties:

....if the direct deployment costs of [SAI] are small compared to the direct benefits a single state receives from deployment, then each capable state would, in principle, seek to deploy [SAI] to a level of their choosing ... the state wanting the greatest degree of cooling - the free driver - would then be the only one to get its wish" (Parker et al. 2018: 1059; see also Wagner and Weitzman 2015).

The need for CG thus rests on the following premise:

The basic free driver characteristic of [SAI] highlights the limitations of a global technology developing in a multipolar international system without an overarching governance framework ... if a state was determined to deploy SRM and was unmoved by the softer tools of statecraft ... there might be little that could be done to stop them beyond military action...(Parker et al. 2018: 1059, my emphasis)

That is, CG technology to countervail or neutralize SAI via warming agents could potentially prevent military conflict. They construct a game-theoretic scenario in which two countries - defined as "rational unitary actors" - have divergent views on SAI deployment: country A wants to deploy, country B does not, and has developed credible CG technology. They demonstrate that, in this highly simplified scenario, the possession of CG can act as an effective deterrent to unilateral deployment (Parker et al. 2018: 1062). Softer deterrence options, such as persuasion, shaming, or sanctions are not guaranteed to work. The same goes for "harder-edged" options in the realm of "gray zone conflict" (e.g. espionage, cyber warfare) leaving only direct military action to stop deployment, which could be viewed as highly disproportionate given the potential to "trigg[er] a systemic war" (p. 1062). Thus, developing effective, credible CG technology is vital to ensure a veto over unilateral deployment, and "could help foster a 'logic of multilateralism' at the core of the international politics of [SAI]" (p. 1063, my emphasis).

Smith and Wagner (2018) construct a scenario for the first 15 years of an SAI program based on the DARPA-funded NCAR/PNNL model of multi-latitude deployment. In their scenario, deployment begins in 2033 with the dispersal of $\sim 0.1 \mathrm{Mt}$ of $\mathrm{S}$ (megatons of sulfur), increasing at a rate of $\sim 0.1 \mathrm{Mt} \mathrm{yr}^{-1}$ linearly thereafter, deployed from latitudes $15^{\circ} \mathrm{N} / \mathrm{S}$ and $30^{\circ} \mathrm{N} / \mathrm{S}$ at an altitude of $\sim 20 \mathrm{~km}$ (Smith and Wagner 2018: 3). They work through options for delivering a large sulfur payload from multiple injection sites at high altitudes, noting that their "main research" on this question "involved engaging directly with commercial aerospace vendors to elicit what current near-term technology platforms can achieve at what cost" (Smith and Wagner 2018: 3, my emphasis). They consulted "directly with: Airbus, Boeing, Bombardier, Gulfstream, GE Engines, Rolls Royce Engines, Atlas Air, Near Space Corporation, Scaled Composites, The Spaceship Company, Virgin Orbit, and NASA" (Smith and Wagner 2018: 3). Six of these companies Airbus, Boeing, GE, Gulfstream (owned by General Dynamics), Rolls Royce, and Scaled Composites (owned by Northrop Grumman) - are among top the 25 major defense contractors in the world. 
Smith and Wagner conclude that delivering large payloads to high altitudes for sustained periods would require revamping military-style aircraft. Maximum deployment by the year 2047 would require 95 aircraft flying 41 flights per day (60,109 per year) from four "bases" to deliver 1.5 million tons of sulfur dioxide to the lower stratosphere (2018: 5). They calculate the total cost at US\$36 billion, which is significantly cheaper than rapid, full-scale energy transitions (e.g. Jacobson et al. 2017), noting that their scenario confirms the calculations of the "free driver" effect (inexpensive), but challenges the notion that SAI could be conducted in secret. The wide-ranging requirements - dozens of planes, thousands of flights, multiple deployment sites - limit possibilities for undetectable unilateral deployment. They therefore argue that "rational actors" must cooperate on SAI deployment (2018: 9).

These scenarios explicitly adopt militarized logics and expertise. They situate SAI deployment in a context of geopolitical brinksmanship wherein "rational" states compete over the power to alter the climate, position military conflict or war as an option of last resort, acknowledge the realities of "gray-zone" conflict via espionage and cyber warfare, envision "deployment" via military-style aircraft from a network of "bases" delivering "payloads", and are reliant upon technological expertise from defense and aerospace corporations that serve as military contractors. Yet, both maintain that SAI will be predicated on cooperation, or a "logic of multilateralism." Such a conclusion is only possible from within the strict confines of Realist IR theory, which reduces geopolitics to a game within the "balance of power." I challenge this approach through a critique of Realist IR, and offer alternative scenarios for SAI deployment that account for the imperial geopolitics of global capitalism.

\section{From the 'balance of power' to stratospheric imperialism}

The above scenarios present a reductionist view of climate politics defined by a dichotomy between "free rider", tragedy of the commons approaches - which have been decisively challenged (Harvey 1974; Wainwright and Mann 2018: 103-108) - and a "free-driver", solar geoengineering approach. The geoengineering "governance imaginary" thus remains wedded to the "neo-neo debate in ... mainstream U.S.-centered international relations" between neorealists and neoliberals (Corry 2017: 303). For neorealists, leading powers could impose a regime of rules for SAI, while for neoliberals, rational state behavior could lead to cooperation and polycentric institutionalization of governance (Corry 2017). Both sides of this "debate" adhere to the core, structural tenets of mainstream Realist IR: territorially sovereign states-as-rational-actors compete for relative power in an anarchical international system where the potential for, or obstacles to, cooperation is the key question (Davenport 2013; Gilpin 1986). The question of unilateralism in the "free driver" framework turns on rational states deploying SAI to protect their national interest against threats posed by climate change, with this capability evenly distributed among a handful of states that have both technological and political capacity to deploy. This adheres to the central problematic of Realist IR: balance of power theory; that is, how states might collectively prevent one actor from amassing the power to alter the climate.

Such (neo)realist approaches constrain understandings of the geopolitics of SAI by obscuring the social roots of power. They exercise a "metaphysical commitment" to axiomatic starting points of sovereignty, anarchy, state rationality, and balance of power predicated on three transhistorical postulates: human nature is defined by a Hobbesian desire for power, nation states concretized this desire in a uniform conception of "national interest", and relations among inherently competitive states are adjudicated through the balance of power (Ashley 1984; Cox 1981: 131). Yet the core tenet of balance of power theory - state sovereignty in conditions of anarchy - is ultimately a product of specifically capitalist social relations (Rosenberg 1994). Capitalist societies are structured by the formal separation of "the economic" from "the political", as surplus extraction is not directly tied to state power but relegated to a private sphere of production (Poulantzas 2000; Wood 1981). As surplus extraction became the province of private firms in "the economy" - the root of capitalist class power - the modern sovereign state "assumed a new centralized monopoly of jurisdiction which it asserts through an impersonal rule of law ... the emergence of distinct institutional spheres called the state and the economy is the signature of capitalist society" (Rosenberg 1994, 125-126). This historical development led to the possibility of a states-system wherein the external relations between states as discrete unitary actors could be theorized. 
In taking this separation as given, balance of power theory fundamentally empties international politics of any theory of the political - of why states compete. What is distinctive about the modern balance of power in mainstream IR theory is its "impersonality, emptiness, abstraction ... [and] scientific technicism" (Rosenberg 1994: 140). Hence Cox $(1981: 128,131)$ understands (neo)realism as a "problemsolving" theory in that it takes "prevailing social and power relationships and the institutions into which they are organized as the given framework for action", with balance of power theory enabling only a flat, horizontal conception of power between states rather than a social conception of class power and a vertical analyses of imperialism. As Rosenberg notes:

Realists tell us that the modern international political system is different because it is a statessystem organized by anarchy rather than an empire organized by centralized command ... but if empire is taken to mean the expansion of political command beyond the territory of the originating community in order to accumulate resources from the outside, then ... the emergence of the modern states-system is actually the development of a new form of imperial power characteristic of a fundamentally new kind of (capitalist) social structure. (Rosenberg 1994: 131, my emphasis)

Capitalist imperialism revolves around hegemonic states fusing capitalist and territorial modes of power to extract and appropriate value from the global periphery (Arrighi 2010; Harvey 2003). The geopolitics of SAI must be placed in the context of capitalist imperialism, which is defined in the present context by U.S. hegemonic decline and the return of inter-imperialist rivalry. I employ Giovanni Arrighi's (2010) account of this process, as he both directly counters Realist IR, and utilizes world systems theory to posit potential scenarios for global capitalism that can broaden geopolitical analyses of SAI.

\section{World hegemony, sovereignty, and the future of U.S. power}

Arrighi acknowledges the formal reality of "anarchy" in modern international politics, but argues that it has always been an ordered anarchy organized through successive "world hegemonies", where "world hegemony" pertains to the ability of a state to "exercise functions of leadership and governance over a system of sovereign states ..." (Arrighi 2010: 28, my emphasis). Historically, this has been accomplished through each regime of world capitalist hegemony - from Genoese, to Dutch, British, and American internalizing costs that were external to the previous regime and expanding the spatio-organizational scope of the global capitalist system (from city-state to U.S. attempts at world empire). The process of internalization-expansion constitutes a "systemic cycle of accumulation", whereby new political-economic configurations that result from struggles over world hegemony generate new phases of material-economic expansion, only to ultimately stagnate and turn toward financialization, which signals the decline of the ruling regime. In this context, Arrighi argues that the U.S. hegemony has reached a state of terminal decline and is increasingly reliant on coercion and violence to sustain its rule, potentially running up against the limits of world-systemic capitalism. He asks: "do the structures of U.S. capitalism constitute the ultimate limit of the six-centuries long process through which capitalist power has attained its present, seemingly all encompassing scale and scope?" (Arrighi 2010: 19). The decline of a leading regime has tended to result in sustained periods of "systemic chaos" and interstate conflict out of which new configurations emerge.

In this context, Arrighi places emphasis on the rise of China and the wider East Asian region. Yet he notes that capitalist history is entering an unprecedented conjuncture wherein financial and military power are increasingly bifurcated, with the former moving towards China, the latter remaining in the hands of the U.S. Given these conditions, Arrighi sees three possible paths: first, the "old centers" - the West led by the U.S. - may succeed in halting the shift to a new regime as they have accumulated massive state- and warmaking powers that "may be in a position to appropriate through force, cunning, or persuasion the surplus capital that accumulates in new centers and thereby terminate capitalist history through the formation of a truly global world empire" (Arrighi 2010: 369). Second, the old centers of power could fail in this endeavor and China may come to lead a renewed era of capitalist hegemony and expanded accumulation. Third, the 
struggle for world hegemony between the U.S. and China could lead to protracted systemic chaos with no structural resolution (Arrighi 2010: 370).

These scenarios broadly align with those proposed by Joel Wainwright and Geoff Mann in Climate Leviathan (2018). Wainwright and Mann argue that climate change will fundamentally challenge central political-economic pillars of modernity: capitalism and sovereignty. Whether capitalism prevails in the midst of climate crisis, and whether sovereignty will be "reconstituted for the purposes of planetary management" are the key political questions. Here I focus on their discussion of planetary sovereignty under "Climate Leviathan", which they root in Carl Schmitt's (1985) theory of sovereignty as the power to decide the exception. For Wainwright and Mann, Climate Leviathan is defined as:

.... regulatory authority armed with democratic legitimacy, binding technical authority on scientific issues, and a panopticon-like capacity to monitor the vital granular elements of our emerging world ... Leviathan will decide and is constituted precisely in the act of decision. It expresses a desire for, and the recognition of, the necessity of a planetary sovereign to seize command, declare an emergency, and bring order to the Earth, all in the name of saving life. (Wainwright and Mann 2018: 30-31, my emphasis)

They argue that solar geoengineering will likely play a fundamental role in this formation of planetary management. While geoengineering would not in and of itself constitute climate Leviathan, "any attempt to modify the world's albedo will require decisions over the fate of the Earth's climate and energy, nothing less than life and death" (Wainwright and Mann 2018: 149), and here they link solar geoengineering to broader processes constructing planetary sovereignty, including space weaponry and capitalism's recurring global economic crises.

Planetary sovereignty is thus constituted in the "necessities crisis and catastrophe demand: hegemonic military-political capacity at a scale adequate to 'save the planet,' the production and protection of geoengineering .... and finally, the sovereign power to name emergency, initiate the institutional and technical responses deemed appropriate, and ensure ... their legitimacy" (Wainwright and Mann 2018: 151). Such a configuration could emerge along two geopolitical paths. The first is a U.S.-centric climate Leviathan wherein the United States maintains its current military dominance "and exploits the 'need to save life on Earth' as the ideological basis of a new imperial hegemony." The second scenario sees U.S. hegemony continue to falter, with planetary governance unfolding on "conflictual geopolitical terrain upon which elites continue to seek 'adaptations' that meet their needs ... [with] the United States and China (or some other small cohort of globally influential powers) deciding to reorganize the world system in a sort of grand compromise that includes shared planetary management" (Wainwright and Mann 2018: 152).

Wainwright and Mann deem the second scenario more likely. Yet, the notion of a "grand compromise" in planetary management elides the fact that solar geoengineering and other forms of planetary governance are deeply interwoven with questions of hegemonic transition, control of energy, imperialist rivalry, and financial and military power, rendering the U.S. and China more likely to compete rather than cooperate in this realm. Hence, I argue that the first scenarios outlined by both Arrighi and Wainwright and Mann - U.S. led efforts to retain hegemony via military dominance - cannot be seen as simply more or less "likely." Rather, this strategy must be pursued by U.S. power, lest the U.S. voluntary surrender its hegemonic position within global capitalism (which is in turn underpinned by U.S. hegemony, Panitch and Gindin 2012). The kind of planetary sovereignty envisioned by Wainwright and Mann - a command and control system organized through multilateral world governance managing a transition to highly diffuse forms of renewable energy - would not merely require a new form of sovereign power, but a fundamentally different form of capitalism and wholesale hegemonic transition. It is entirely conceivable that capitalism can thrive within a renewable energy regime (McCarthy 2015), but there is no guarantee that this would be capitalism under U.S. hegemony, and would require capital to systematically abandon many traditional - and in some cases fundamental - sources of power (namely: cheap, highly concentrated energy subsidized by imperial violence, see Malm 2016; Mitchell 2009; Moore 2015). 
Wainwright and Mann's account of solar geoengineering as a tactic in capital's attempt to maintain hegemony in the midst of the climate crisis is illuminating, but relies too heavily on notions of emergency decision wherein solar geoengineering only emerges via new forms of sovereignty, or as part of a "new imperial hegemony." The capacity to "intervene" in the climate system is already immanent to imperial powers of intervention under existing international law and the sovereign states-system, and can be mobilized to prevent the emergence of new or shared sovereign power. The power to declare a planetary emergency and intervene in the climate might well represent or augur a new form of sovereignty, but the power to enact this intervention is not contingent upon the development of a new sovereign formation, as it its entirely possible - and fits logically - within current forms of U.S. imperialism. I flesh this out by detailing ways in which fossil fuels (particularly oil), the dollar, and military dominance fundamentally undergird the relationship between U.S. hegemony and global capitalism. This is then juxtaposed to the U.S. military's approach to climate security and the command of the global commons to situate SAI - a preemptive climate intervention to bridge the dichotomous goals of fossil fuel expansion and climate stability - as a potential (and logical) extension of current U.S. geopolitical strategy. The complexities found in the relationship between U.S. imperialism and fossil fuels, climate security, and planetary-scale intervention constitute the geopolitical ecology of solar geoengineering.

\section{Militarized fossil capital: the material substrates of U.S. power}

Oil has been integral to U.S. power since the early twentieth century, underwriting its emergence as the predominant "mass society" of the era by making possible "motive power; new kinds of industrial and agricultural possibilities based on synthetic chemicals, urbanization and, especially, suburbanization; and, perhaps most importantly, mass transportation in both the civilian and military sectors" (Bromley 2008: 107; see also Huber 2013). Oil became strategically linked to U.S. hegemony in the waning days of WWII, as struggles over the fall of British hegemony and the rise of U.S. power were bound up with "mechanisms that tied together democracy in the West, flows of oil and the value of the US dollar" (Mitchell 2009: 413). U.S. strategy centered on controlling pipelines and linking the dollar to oil in postwar planning:

... what sustained the value of the dollar was its convertibility not to gold but to oil. In both value and volume, oil was the largest commodity in world trade. In 1945 the United States produced two-thirds of the world's oil. As production in the Middle East was developed, and the routes of pipelines plotted, most of this overseas oil was also under control of American companies. Under the peculiar arrangements that governed the international oil trade, the commodity was purchased ... largely in US dollars. (Mitchell 2009: 414).

Beginning in 1945 with negotiations between President Roosevelt and Saudi King Ibun Saud, and cemented in 1953 via the CIA orchestrated coup of Mohammad Mossadegh in Iran, the U.S. established a systematic relationship between Middle Eastern autocrats, oil corporations, and security agencies to ensure the stability of a region deemed vital to U.S. interests (Jones 2012).

This inaugurated what Lehmann (2019) calls the "1954 American Hegemonic System." U.S. grand strategy has been predicated upon control over Middle Eastern oil not for direct imports, but to tie dependent spokes to a U.S. hub:

The system meant dollar-priced Middle Eastern oil flowed to American allies in Europe and Asia, who re-developed their postwar industrial and transport systems on an oil-basis while also pursuing export-led growth models based on exports to the US consumer market. The US discriminated positively in favor of these allied imports ... purposively choosing a path of deindustrialization, trade deficit promotion, and the use of American consumerism to tie dependent ally spokes to the US hub. As long as American consumers could purchase these imports and allied exporters earned enough dollars to pay for oil imports to fuel their own growth, the system maintained itself ... (Lehmann 2019: 434-435) 
OPEC nationalization, increasing oil prices, and abandonment of the gold standard in the early 1970s did not fundamentally alter "the system." Price increases were encouraged by Western oil majors, and the Nixon Administration pushed Saudi Arabia - the dominant oil producer in OPEC - to continue invoicing oil in U.S. dollars, use accumulating "petrodollars" to purchase U.S. treasuries, and to recycle liquidity through Eurodollar markets (increasing debt crises and dependency across the Global South). The guided purchase of U.S. government debt kept interests rates low and propped up U.S. consumer spending (Momani 2008; Sprio 1999; Vasudevan 2008). By the 1980s OPEC's direct power over pricing was superseded by growth in oil markets, which kept oil priced in U.S. dollars (the "incumbent" currency in international finance) but financialized oil production, semi-divorcing price from material production and supply (Labban 2010; Smith-Nonini 2016).

OPEC and financialization wrested direct power over production and pricing from Western oil majors, disrupting a key component of the "American system", necessitating more coercive measures via U.S. imperial intervention. As Jones (2012: 210) argues, American "oil wars" - particularly since the Carter Doctrine of 1980 - have "not been about establishing direct control over oil fields nor about liberation" or freedom; rather, "keeping prices stable (not low) and keeping pro-American regimes in power were central to U.S. strategic policy." This required a geostrategic reconfiguration of the region via the creation of U.S. Central Command in 1983, which key military officials openly link to U.S. imperialism, the flow of oil, and global capitalism: "...the Central Region has continued to grow in importance ... Maintaining stability in this volatile region is key to the free flow of oil and other commerce essential to the world economy" (U.S. Central Command 2005, cited in Morrissey 2016: 19).

Further, the flow of oil out of the region has not been the only important "flow" related to U.S. imperialism:

By the early 1970s, the Middle East had become the focus of two important flows - receipts from weapon imports into the region and revenues from oil exports out of it. Underpinning these two flows ... [was] a formidable global alliance between the integrated oil companies, the large armament contractors, leading Western countries, and key oil-producing countries. (Bichler and Nitzan 2015: 57).

Bichler and Nitzan (2015) argue that capital is primarily driven by differential accumulation, demonstrating that when the rate of accumulation among leading oil majors dips below the average in the Fortune 500, an "energy conflict" in the Middle East often follows. This provides a rationale for raising prices, and new revenues (and rationales) for massive arms sales to oil producing countries by U.S. defense contractors. Thus, while the militarized oil-dollar system does - fundamentally - "secure the flow" of oil for global capitalism, this is no mere public good: it benefits U.S. hegemony, which retains a monopoly on the ability to secure this flow and the currency in which it is priced and traded (Stokes 2007), proving particularly beneficial to "nationalistic" fractions of U.S. capital such as energy and defense firms (Bieler and Morton 2015; see also Hudson 2020).

\section{Maintaining hegemony in the midst of climate crisis}

This "dual logic" of U.S. imperialism - securing oil for global capitalism to enhance the relative hegemony of the U.S. - leads Lehmann to conclude that the Iraq War was not, in fact, a strategic blunder. The war certainly did not go as planned, but it ultimately served to further the core, material processes undergirding U.S. dominance:

Iraq's oil and natural gas are controlled by ExxonMobil, Royal Dutch Shell, and other subordinate partners. Iraq's oil and gas are used to influence other's consumption and deference to US leadership of world energy. The Chinese, Russians and others are junior stakeholders in this system, not upstarts who have gained at US expense ... and U.S. weapons 
sales have cemented dependency of Iraq in different yet overlapping ways along with IMF indebtedness and dependence on Houston's technical prowess. Were these the objects of the war, as opposed to unintended results from the chaos of war and occupation? (Lehmann 2019: 438)

The U.S. has essentially been able to maintain this crucial aspect of its power and place within global capitalism (yet, to be sure, this has come at considerable costs with no certainty of stability). Another key element - and unintended consequence - was the Iraq War's role in catalyzing major investments in and expansion of domestic U.S. fossil fuel extraction (Lehmann 2019: 437-438), with the U.S. now the largest producer (and a leading exporter) of both oil and natural gas (Brown and Kahan 2019). With Western, dollar-denominated, militarized control over a key oil and gas producing region, and a commanding position in domestic oil and gas production, U.S. geopolitical strategy is fundamentally predicated on maintaining the centrality of oil and gas in global capitalism, and maintaining the oil-dollar regime by keeping China, the wider East Asian region, and other allies fundamentally dependent on imported oil - from the U.S. and Middle East sources - for the foreseeable future. ${ }^{8}$

There are myriad potential obstacles to this strategy, not least of which include the potential decline in financial viability in the fossil fuel sector and the simultaneous rise of China's commanding position in renewable energy production and infrastructure (see Harris 2019; Mercure et al. 2018; Surprise 2018). Despite these potential challenges, the U.S. appears to be in a strong position. ${ }^{9}$ China is now the largest energy consumer and oil importer in the world (Barron 2018), importing over 70 percent of its crude oil in 2018 - over half from Middle East sources - with imports projected to hit 80 percent by 2040, and similar trends emerging in natural gas (Nakano and Stanley 2018). Moreover, global capital appears wedded to fossil fuels for the foreseeable future. Although the renewable energy sector is expanding, the capitalization of the global fossil fuel industry continues to dwarf that of renewables, with the oil and gas sectors, including publicly traded companies and state-owned enterprises, totaling approximately US\$6.7 trillion (DiMuzio 2016; DiMuzio and Dow 2019). Capitalization is a bet on the future. As Foster et al. 2019 note, "oil and gas pipeline expansion plans (preconstruction and construction) in North America currently amount to \$232 billion (over $\$ 600$ billion globally)", thus "banks, equity investors, and bondholders are in the process of placing over $\$ 600$ billion in bets on an expanded pipeline system ... with an expected lifespan of 40 years or more" (Foster et al. 2019). Indeed, in the three years after the 2015 Paris Accords, JPMorgan Chase alone invested US\$196 billion in fossil fuel expansion globally (McKibben 2019).

Given that the militarized-oil-dollar U.S. regime continues to underwrite global capital, Foster et al. (2019) argue that the Trump Administration's militarization of energy policy should be understood in the context of emergent inter-imperialist rivalry: "...the dollar-oil-Pentagon regime ... is exerting all of its military and financial power to gain geopolitical and geoeconomic advantages. The goal is to subordinate still further those countries at the bottom of the world hierarchy, while putting obstacles in the way of emerging economies." Hence the 2017 National Defense Strategy links domestic energy production to geopolitical positioning against "great power competitors", amounting to a "new strategy of energy imperialism, in which U.S. preeminence in the control of world energy and a commitment to maximal fossil fuel extraction have been placed at the center of today's national security objectives" (Foster et al. 2019).

\footnotetext{
${ }^{8}$ This is compounded by the fact that in recent decades Venezuela, Iraq, Russia, and China have flirted with selling or purchasing oil in other currencies, with China recently seeking to establish a "petroyuan" (Huang 2019).

9 This paper was written well before the Coronavirus outbreak and the Russia-Saudi oil price war, the combination of which could permanently alter oil markets and the centrality of fossil fuels in global energy (Ladislaw and Cahill 2020). It remains too soon to tell. Yet, signals abound that the U.S. is using the crisis to strengthen its hand in oil geopolitics (e.g. with Venezuela [Spetalnick 2020] and Iran [Hasan 2020]), and will use the coming recession and recovery to propup the fledgling oil and gas sectors (e.g. suspending Environmental Protection Agency regulations, reversing auto mileage standards, potentially imposing tariffs on oil imports) (InfluenceMap 2020).
} 
Yet, in the mist of this fossil-driven strategy, the U.S. defense establishment continues to view climate change as a threat to national security - and this is the context in which SAI should be understood as a potentially strategic asset. The U.S. military does not see climate change as a threat as such, but rather the turbulence that a changing climate can inject into the workings of empire (Cooper 2010: 183, my emphasis): "Within current US strategizing ... climate change has become a security concern not only because it poses political risks of its own ... but also because it is inseparable from the larger issues of energy security, energy transition, and the exceptional role of the dollar within world financial flows." Cooper (2010: 184) suggests that SAI fits logically into U.S. strategies predicated on preemption, in that it potentially offers a "strategic intervention into the atmosphere to preempt the worst effects of climate change", and thus generate more manageable forms of turbulence. SAI is not a panacea. Every model and scenario demonstrates that it must be paired with emissions cuts; however, it could buy time - conceivably decades - to slow and manage climate and energy transitions in the interest of the U.S. hegemonic position undergirding global capital.

\section{Jus ad climate? Climate security, U.S. imperialism, and international law}

That the U.S. military views climate change as a threat to national security and a direct threat to its mission has not changed amidst the Trump Administration's denialism (Roberts 2018; Werrell and Femia 2019). The military considers climate change a "threat multiplier", with the 2014 Quadrennial Defense Review noting that climate change will "influence resource competition while placing additional burdens on economies, societies, and governance institutions around the world. These effects are threat multipliers that will aggravate stressors abroad such as poverty, environmental degradation, and political instability" (Hagel 2014: 8). Here climate-induced drought, heat waves, flooding and sea-level rise exacerbate conditions of famine, disasters, disease, "failed states", and mass migration that are viewed as external threats to the homeland (Gilbert 2012).

Managing new conflict and disaster zones could stretch the military's operational capacity, with climate impacts already threatening military readiness. A DoD White Paper entitled "Report on effect of a changing climate to the Department of Defense" (identifies 79 mission-critical bases that are experiencing or extremely vulnerable to climate-driven flooding, drought, desertification, and wildfires. The "background" to the report reads (Office of the Undersecretary of Defense for Acquisition and Sustainment 2019: 2):

The effects of a changing climate are a national security issue with potential impacts to Department of Defense ... Our 2018 National Defense Strategy prioritizes long-term strategic competition with great power competitors ... to achieve these goals, DoD must be able to adapt current and future operations to address the impacts of a variety of threats and conditions, including those from weather and natural events. To that end, DoD factors in the effects of the environment into its mission planning and execution to build resilience.

This report situates climate security within broader strategic priorities defined by "great power competition." The U.S. position in "great power competition" is inextricably tied to the expansion of fossil fuels, again pointing to the potentially strategic utility of SAI.

Further still, if a changing climate is deemed a threat to U.S. national security and military capacity, it would hold that any deliberate attempt to change the climate would be considered, ipso facto, a security threat. It is difficult to imagine the U.S. ceding this power to any other actor, unless through a partnership in which it was the dominant player. Solar geoengineering could be considered, then, an emerging aspect of U.S. "command of the commons" - air, sea, space and cyberspace. As Posen (2003: 8) argues, "command of the commons is the key military enabler of the U.S. global power position." This "command" does not preclude other states utilizing or even placing military assets in the commons, but it does grant the U.S. greater access and the capacity to credibly deny use to others, through military force if necessary (Fluornoy and Brimley 2009; Murphy 2010). 
U.S. command of the commons has been advanced since WWII, but became truly global via the doctrine of "full spectrum dominance" that seeks a totalized, networked form of geopolitical power (Cooper 2006; Hardt and Negri 2005; Massumi 2015). As Aatolta et al. argue, the American notion of the

...final frontier has not been for long a geographical barrier, but a function of making power as moveable and mouldable as possible ... engineering various agile policies and technologies that integrate the sea, air, space, and cyber domains ... the emergence of a truly integrated mobile form of power. (Aatolta et al. 2014: 47)

U.S. military command now sees strategic regions as geo-economic "continuums" with blurry boundaries between borders, economy, environment, and security. Climate change exacerbates and reinforces this expansive notion of U.S. global intervention, as it "re-endorses the military's strategic entry into all places and spaces. Climate change is constructed as omniscient, and an enemy to all ..." (Chaturvedi and Doyle 2015: 139). The conception of climate change as an emergent, planetary-scale threat expands U.S. strategies of preemption and 'full spectrum dominance" throughout the global commons - including the stratosphere.

This is the context in which The Pentagon is developing a so-called "triple canopy" network of drones, planes, balloons, satellites, reconnaissance instruments, and weaponry to enhance kinetic operations (McCoy 2017). The "triple canopy" would enable communications and operations for "the Army's ground and mobile forces, the Air Forces airborne terminals, Navy ships at sea, the White House Communications Agency, the State Department ... the CIA, and NSA, among other agencies" (McCoy 2017: 183). Key features of this network operate in or through the stratosphere. For example, a report by the Army Capabilities Integration Future Warfare Center envisions, by 2028, a "Space Brigade" capable of deploying stratospheric/high altitude platforms

...carrying tailorable payloads... [to] provide capabilities to formations across the operational framework. These systems can conduct reconnaissance, surveillance, and target acquisition; relay data for command, control, communications, computers and intelligence, surveillance ... and provide positioning, navigation, and timing. (U.S. Army 2018) ${ }^{10}$

If the U.S. military is systematically enrolling the stratosphere into strategic operations, any form of SAI deployment would - at the very least - likely require clearance by DoD, if not outright control to ensure continuity of strategy across the stratospheric commons.

Hence Nightingale and Cairns (2014) argue that SAI would be classified as "critical national infrastructure." This would render the entirety of SAI deployment subject to a range of high-level securitization, including: logistics of sourcing, manufacturing, and transporting sulfur; protection of deployment "bases" from hostile states, terrorism, and extreme forms of environmental protest; ensuring the integrity of aircraft and flights (e.g. maintaining deployment systems for decades, if not longer); creating systems of redundancy and the capacity to surveil, monitor, and adjust deployment; and use of this monitoring capacity to locate and prevent any counter-geoengineering attempts, which could require military force (see also Lockley 2019). Such logistical, security, and enforcement mechanisms could conceivably operate under international civilian governance systems, but this is unlikely for two reasons: first, as has been noted, militaries have the techno-logistical expertise necessary for operating and protecting global networks of sensitive critical infrastructure over long periods of time. Second, SAI cannot merely be considered a cooperative public good, as its development is fundamentally interwoven with questions of imperial power.

10 This was written before the formal creation of the United States Space Force, which would presumably undertake these operations. 
Imperialism, law, and climate intervention

Finally, whether a militarized (but not explicitly hostile or offensive) approach to SAI would be considered legitimate or justifiable under international law remains unclear. A recent argument by Chalecki and Ferarri (2018) explores this question, and is of note for two reasons: first, it is published in Strategic Studies Quarterly - "the peer-reviewed strategic journal of the United States Air Force." Second, it explicitly frames geoengineering deployment as akin to war, exploring prospects for ethical governance under "just war" doctrine. They outline various international laws and conventions that could potentially cover solar geoengineering, noting that there is nothing in international law explicitly prohibiting deployment for "defensive" purposes, wherein the "national security problems engendered by the changing climate have become so severe" that solar geoengineering moves from potential threat to security strategy (Chalecki and Ferarri 2018: 92).

They analyze "defensive" geoengineering through jus ad bellum (law of resort to force) and jus in bello (law of war conduct). For jus ad climate - the resort to climate intervention - "a state must be facing a major climate-related security emergency to justify using geoengineering ... however, as in just war theory, this criterion is extremely subjective" (Chalecki and Ferarri 2018: 95). This aligns with the increasingly recognized understanding that deployment and cannot be based on objective conditions of "climate emergency." Once a so-called "climate tipping point" might have been reached, there is no guarantee that reactive, emergency geoengineering can repair the damage. Rather, SAI cannot prevent a climate emergency "unless it is declared preemptively on the sole basis of unabated greenhouse gas emissions" in which case it would be "analogous to preemptive warfare" (Sillmann et al. 2015: 292, my emphasis; see also Markusson et al. 2014; Surprise 2018).

Positioning SAI - climate intervention - as akin to preemptive warfare fits with recent U.S. strategy concerning "interventions" under international law. Recent U.S. interventions in Kosovo, Iraq, Libya, wideranging drone strikes, and so on have sought legal justification not only through traditional channels (e.g. the UN Security Council), but also through recourse to novel legal rationales due to the reemergence of inter-imperialist rivalry in global politics (Knox 2013). China, Russia, and others can strategically and credibly block some U.S. actions through the Security Council, forcing the U.S. to find exceptional legal means to justify imperial violence via preemptive and "humanitarian" interventions. Law and violence are not in opposition: law is always established by and maintained through violence. The basic units of international politics - sovereign states - are juridical forms created by colonial conquest, rendering states both the subjects of law and the wielders of violence (Miéville 2005: 286). Capitalist geopolitics are not merely about power relations in which law plays a shaping or constraining role; rather, "the power politics of modernity are the power politics of a juridically constructed system" (Miéville 2005: 284). In this context, what counts as law, and what is enforced, are not transversal categories but political relations backed by force.

As Miéville (2005) argues, this does not mean that international law is merely an ideological smoke screen for imperialism: it is imperialism. Violence and intervention (preemptive war, "just" war, humanitarian intervention) are written into the very structure of capitalist world order predicated on sovereign states operating as juridical entities. Interpretive debates over whether interventions are "legal" could go on endlessly, but "legal arguments do not go on forever ... their resolution is not a result of the internal logic of concepts, but represents interpretation backed by force" (p. 284, original emphasis). As all sovereign states are formally equal juridical subjects under international law, and there is no global authority to act as final arbiter between competing claims, Miéville likens this to Marx's analyses of the "equal rights" afforded to both capitalists and workers in liberal legal regimes: between equal rights, force decides.

Thus, Miéville argues (2005: 292-293, original emphasis):

In the politically and militarily unequal modern world system ... the international legal form assumes juridical equality and unequal violence ... the necessity of this unequal violence derives precisely from juridical equality: one of the legal subjects makes law out of the legal relation by means of their coercive power - their imperialist domination. 
Applying this logic to solar geoengineering suggests that the power to preemptively intervene in the climate system is already immanent to contemporary forms of imperialism within international law, and would not necessarily require or constitute an entirely new sovereign political configuration. Rather, it could be mobilized to preempt the emergence of such a configuration, as cooperative, multilateral control over climate and energy by capitalist powers - in the plural - could threaten the U.S. led capitalist system. Whether, in Wainwright and Mann's terms, unilateral control of climate management requiring "decisions over the fate of the Earth's climate and energy" would constitute a new form of sovereign power is an open question. Yet, the political and even "legal" power to intervene in the climate already exists under the current structures of U.S. empire. Analyses of planetary-scale power need not wait for new or extreme political formations, but rather pay close attention to the gradual processes through which U.S. military and intelligence agencies - and the broader U.S. state - are constructing the technological and political capabilities for climate intervention.

\section{Conclusion}

Solar geoengineering is gaining traction in climate policy, with governance emerging as central concern and growing recognition that scenarios for potential deployment shape the design of governance mechanisms. This necessitates closer attention to the ideological positions undergirding scenario construction. The U.S. military, intelligence, and foreign policy establishment has been directly involved in shaping the solar geoengineering governance field, from funding research to hosting conferences, producing reports, and providing congressional testimony. This influence is evident in recent scenarios that adopt military language, logics, and expertise, undergirded by a highly specific understanding of international politics informed by the axiomatic tenets of Realist IR theory. Counter-intuitively, these scenarios ultimately argue that solar geoengineering governance will be driven by a "logic of multilateralism", but such assessments lack an analysis of capitalist imperialism and a notion of strategic (rather than tactical) unilateral deployment.

Drawing on world systems theory and geopolitical ecology, I have explored scenarios in which SAI could hold strategic significance for U.S. hegemony predicated on the expansion of fossil fuels in the midst of a climate "security" crisis. This analysis suggests that forms of "planetary sovereignty" will not necessarily require entirely novel political configurations, but could emerge via existing forms of imperial intervention written into the structures of international law. Solar geoengineering and the and geopolitical ecologies of climate intervention are immanent to the structures of global capitalist geopolitics - not extreme aberrations - and intimately bound up with questions of world hegemony, control of energy, financial flows, and military-imperial dominance. Scenarios for unilateral SAI deployment need to take these processes into account.

\section{References}

Aaltola, M., J. Käpylä, H. Mikkola and T. Behr. 2014. Towards the geopolitics of flows. FIIA Report 40. Finnish Institute of International Affairs.

Agamben, G. 2005. State of exception. Chicago: University of Chicago Press.

Arrighi, G. 2010. The long Twentieth Century: money, power, and the origins of our times. London: Verso.

Ashley, R.K. 1984. The poverty of neorealism. International Organization 38(2): 225-286.

Barron, J. 2018. China surpassed the United States as the world's largest crude oil importer in 2017. $\begin{array}{lllll}\text { International Energy } & \text { Agency. } & \text { [accessed }\end{array}$ https://www.eia.gov/todayinenergy/detail.php?id=34812

Baskin, J. 2019. Geoengineering, the Anthropocene and the end of nature. London: Palgrave.

Belcher, O., P. Bigger, B. Neimark and C. Kennelly. 2020. Hidden carbon costs of the "everywhere war": logistics, geopolitical ecology, and the carbon boot-print of the US military. Transactions of the Institute of British Geographers 45(1): 65-80. 
Bernazzoli, R.M. and C. Flint. 2009. From militarization to securitization: finding a concept that works. Political Geography 8(28): 449-450.

Bichler, S. and J. Nitzan. 2015. Still about oil? Real-World Economics Review (70): 49-79.

Bieler, A. and A.D. Morton. 2015. Axis of evil or access to diesel? Spaces of new imperialism and the Iraq war. Historical Materialism 23(2): 94-130.

Bigger, P. and B. Neimark. 2017. Weaponizing nature: the geopolitical ecology of the US Navy's biofuel program. Political Geography 60: 13-22.

Bipartisan Policy Center (BPC). 2011. Geoengineering: a national strategic plan for research on the potential effectiveness, feasibility, and consequences of climate remediation technologies. Washington, DC: Bipartisan Policy Center Task Force on Climate Remediation Research.

Blackstock, J.J., D.S. Battisti, K. Caldeira, D.M. Eardley, J.I. Katz, D.W. Keith, A.A.N. Patrinos, D.P. Schrag, R.H. Socolow and S.E. Koonin. 2009. Climate engineering responses to climate emergencies. Novim. [accessed March 15 2019] https://arxiv.org/abs/0907.5140

Bromley, S. 2008. American power and the prospects for international order. Cambridge: Polity.

Brosig, M., P. Frawley, A. Hill, M. Jahn, M. Marsicek, A. Paris, M. Rose, A. Shambaljamts and N. Thomas. 2019. Implications of climate change for the U.S. Army. Carlisle, PA: U.S. Army War College.

Brown, B. and A. Kahan. 2019. The U.S. leads global petroleum and natural gas production with record growth in 2018. International Energy Agency [accessed August 12 2019] https://www.eia.gov/todayinenergy/detail.php?id=40973

Buck, H.J. 2012. Geoengineering: re-making climate for profit or humanitarian intervention? Development and Change 43(1): 253-270.

Burns, L. and D. Keith. 2018. Solar geoengineering. Boston Tech Hub Faculty Working Group [accessed January 21 2020]

https://www.belfercenter.org/sites/default/files/files/publication/FWG\%20Fall\%202018\%20Sessio n\%202_Solar\%20Geoengineering.pdf

Büscher, B. and R. Fletcher. 2018. Under pressure: conceptualising political ecologies of green wars. Conservation and Society 16(2): 105-113.

Chalecki, E.L. and L.L. Ferrari. 2018. A new security framework for geoengineering. Strategic Studies Quarterly 12(2): 82-107.

Chaturvedi, S. and T. Doyle. 2015. Climate terror: a critical geopolitics of climate change. London: Palgrave Macmillan.

Chemnick, J. 2019. U.S. blocks U.N. resolution on geoengineering. Scientific American [accessed September 5 2019] https://www.scientificamerican.com/article/u-s-blocks-u-n-resolution-ongeoengineering/

Chhetri, N., D. Chong, K. Conca, R. Falk, A. Gillespie, A. Gupta, S. Jinnah, P. Kashwan, M. Lahsen, A. Light, C. McKinnon, L.P. Thiele, W. Valdivia, P. Wapner, D. Morrow, C. Turkaly and S. Nicholson. 2018. Governing solar radiation management. Report from the Academic Working Group on Climate Engineering Governance, Forum for Climate Engineering Assessment. Washington, D.C.: American University.

Cooper, M. 2006. Pre-empting emergence: the biological turn in the war on terror. Theory, Culture and Society 23(4): 113-135.

Cooper M. 2010. Turbulent worlds. Theory, Culture and Society 27(2-3): 167-190.

Corry, O. 2017. The international politics of geoengineering: The feasibility of Plan B for tackling climate change. Security Dialogue 48(4): 297-315.

Cox, R.W. 1981. Social forces, states and world orders: beyond international relations theory. Millennium 10(2): 126-155.

Dalby, S. 2013a. The geopolitics of climate change. Political Geography 37: 38-47.

Dalby, S. 2013b. Biopolitics and climate security in the Anthropocene. Geoforum 49: 184-192. 
Dalby, S. 2015. Geoengineering: the next era of geopolitics? Geography Compass 9(4): 190-201.

Davenport A. 2013. Marxism in IR: Condemned to a realist fate? European Journal of International Relations 19(1): 27-48.

Di Muzio, T. 2016. Energy, capital as power and world order. In Cafruny A., L. Talani and G. Pozo Martin (eds.) The Palgrave handbook of critical international political economy. London: Palgrave Macmillan. Pp. 267-287.

Di Muzio, T. and M. Dow. 2019. Carbon capitalism and world order. In Cafruny A., L. Talani and G. Pozo Martin (eds.) The Palgrave handbook of critical international political economy. London: Palgrave Macmillan. Pp. 555-570.

Duffy, R. 2016. War, by conservation. Geoforum 69: 238-248.

Dykema J.A., D.W. Keith, J.G. Anderson and D. Weisenstein. 2014. Stratospheric controlled perturbation experiment: a small-scale experiment to improve understanding of the risks of solar geoengineering. Phil. Trans. R. Soc. A 372(2031): 20140059.

Edwards, P.N. 1997. The closed world: computers and the politics of discourse in Cold War America. Cambridge: MIT Press.

Femia, F. and C. Werell. 2019. Chronology of U.S. Military statements and actions on climate change and security: Jan 2017-August 2019. Center for Climate and Security. [accessed August 5 2019] https://climateandsecurity.org/2019/08/22/update-chronology-of-u-s-military-statements-andactions-on-climate-change-and-security-jan-2017-august-2019/

Fleming, J.R. 2010. Fixing the sky: the checkered history of weather and climate control. New York: Columbia University Press.

Flournoy, M. and S. Brimley. 2009. The contested commons. US Naval Institute, Proceedings 135(7). [accessed April 5 2020] http://indianstrategicknowledgeonline.com/web/The\%20Contested\%20Commons,\%20Flournoy,\% 20Brimley.pdf

Foster, J., H. Holleman and B. Clark. 2019. Imperialism in the Anthropocene. Monthly Review. [accessed September 10 2019] https://monthlyreview.org/2019/07/01/imperialism-in-the-anthropocene/

Gilbert, E. 2012. The militarization of climate change. ACME: An International E-Journal for Critical Geographies 11(1): 1-14.

Gilpin, R. 1986. The political economy of international relations. Princeton, NJ: Princeton University Press.

Golden, D. 2017. Spy Schools: how the CIA, FBI, and foreign intelligence secretly exploit America's universities. New York: Henry Holt and Company.

Govindasamy, B. and K. Caldeira. 2000. Geoengineering Earth's radiation balance to mitigate CO2-induced climate change. Geophysical Research Letters 27(14): 2141-2144.

Hagel, C. 2014. Quadrennial Defense Review. Washington, DC: Department of Defense.

Hamilton C. 2013. Earthmasters: the dawn of the age of climate engineering. New Haven: Yale University Press.

Hardt, M. and A. Negri. 2005. Multitude. London: Penguin.

Harris, J. 2019. The future of globalisation: neo-fascism or the Green New Deal. Race and Class 61(1): 325.

Harvey, D. 1974. Population, resources, and the ideology of science. Economic Geography 50(3): 256-277.

Harvey D. 2003. The new imperialism. Oxford: Oxford University Press.

Hasan, M. 2020. Beware of Trump using the Coronavirus as cover for war with Iran. The Intercept. [accessed April 5 2020] https://theintercept.com/2020/03/30/trump-iran-war-coronavirus/

Horton, J. B. 2011. Geoengineering and the myth of unilateralism: pressures and prospects for international cooperation. Stanford Journal of Law, Science and Policy (4): 56-69.

Horton, J.B. and J.L. Reynolds. 2016. The international politics of climate engineering: a review and prospectus for international relations. International Studies Review 18(3): 438-461. 
Huang, E. 2020. A 'growing club' of 'of very powerful countries' is steering away from using the dollar. CNBC News. [accessed January 30 2020] https://www.cnbc.com/2019/10/31/de-dollarizationrussia-china-eu-are-motivated-to-shift-from-using-usd.html

Huber, M.T. 2013. Lifeblood: oil, freedom, and the forces of capital. Minneapolis, MN: University of Minnesota Press.

Hudson, M. 2020. Will America escalate its "democratic" oil war in the Near East? Counterpunch. [accessed April 5 2020] https://www.counterpunch.org/2020/01/06/america-escalates-itsdemocratic-oil-war-in-the-near-east/

Hulme, M. 2014. Can science fix climate change? A case against climate engineering. Hoboken, NJ: John Wiley and Sons.

InfluenceMap. 2020. Tracking corporate climate lobbying in response to the COVID-19 crisis. [accessed April 5 2020]

https://influencemap.org/site/data/000/486/InfluenceMap_CoronavirusClimateLobby_April2020.pdf

Irvine, P., K. Emanuel, J. He, L.W. Horowitz, G. Vecchi and D. Keith. 2019. Halving warming with idealized solar geoengineering moderates key climate hazards. Nature Climate Change 9(4): 295.

Jones T.C. 2012. America, oil, and war in the Middle East. The Journal of American History (99)1: 208218.

Keith, D.W. 2000. Geoengineering the climate: history and prospect. Annual Review of Energy and the Environment 25(1): 245-284.

Keith, D.W. 2013. A case for climate engineering. Cambridge, MA: The MIT Press.

Keith, D.W. 2019. Harvard's Solar Geoengineering Research Program. Presented at the National Academies of Sciences, Engineering, and Medicine: Developing a research agenda and governance process for climate intervention strategies that reflect sunlight to cool Earth. [accessed April 30 2019] http://nassites.org/dels/studies/reflecting-sunlight-to-cool-earth/meetings-and-events/

Keith, D.W., E. Parson and M.G. Morgan. 2010. Research on global sun block needed now. Nature 463(7280): 426-427.

Keith, D.W. and D.G. MacMartin. 2015. A temporary, moderate and responsive scenario for solar geoengineering. Nature Climate Change 5(3): 201-206.

Kintisch, E. 2009. DARPA to explore geoengineering. [accessed June 5 2019] https://www.sciencemag.org/news/2009/03/darpa-explore-geoengineering

Knox, R. 2013. Civilizing interventions? Race, war and international law. Cambridge Review of International Affairs 26(1): 111-132.

Kravitz, B., D.G. MacMartin, M.J. Mills, J.H. Richter, S. Tilmes, J.F. Lamarque, J.J. Tribbia and F. Vitt. 2017. First simulations of designing stratospheric sulfate aerosol geoengineering to meet multiple simultaneous climate objectives. Journal of Geophysical Research: Atmospheres 122(23): 612-616.

Labban, M. 2010. Oil in parallax: scarcity, markets, and the financialization of accumulation. Geoforum 41(4): 541-552.

Ladislaw, S. and B. Cahill. 2020. Is the oil market crisis over? Not at all. Center for Strategic and International Studies. [accessed April 5 2020] https://www.csis.org/analysis/oil-market-crisis-overnot-all

Lane, L., K. Calderia, R. Chatfield and S. Langhoff. 2007. Workshop report on managing solar radiation. National Aeronautics and Space Administration Ames Research Center. [accessed July 16 2019] https://ntrs.nasa.gov/archive/nasa/casi.ntrs.nasa.gov/20070031204.pdf

Lehmann, T.C. 2019. Honourable spoils? The Iraq War and the American hegemonic system's eternal and perpetual interest in oil. The Extractive Industries and Society 6(2): 428-442.

Lempert, R.J. and D. Prosnitz. 2011. Governing geoengineering research: a political and technical vulnerability analysis of potential near-term options. Santa Monica, CA: The RAND Corporation. 
Liebelson, D. and C. Mooney. 2013. Climate Intelligence Agency. Slate. [accessed July 15 2019] https://slate.com/technology/2013/07/cia-funds-nas-study-into-geoengineering-and-climatechange.html

Lockley, A. 2019. Security of solar radiation management geoengineering. Frontiers of Engineering Management 6(1): 102-116.

Low, S. 2017. Engineering imaginaries: anticipatory foresight for solar radiation management governance. Science of the Total Environment 580: 90-104.

Lunstrum, E. 2014. Green militarization: anti-poaching efforts and the spatial contours of Kruger National Park. Annals of the Association of American Geographers 104(4): 816-832.

Lutz, C. 2002. Making war at home in the United States: militarization and the current crisis. American Anthropologist 104(3): 723-735.

Lutz, C. 2004. Militarization. In Nugent D. and J. Vincent (eds.) A companion to the anthropology of politics. Malden, MA: Wiley Blackwell. Pp. 318-331.

Maas, A. and J. Scheffran. 2012. Climate conflicts 2.0? Climate engineering as a challenge for international peace and security. S\&F Sicherheit und Frieden 30(4): 193-200.

MacMartin, D.G., K. Caldeira and D.W. Keith. 2014. Solar geoengineering to limit the rate of temperature change. Phil. Trans. R. Soc. A 372(2031): 20140134.

Malm, A. 2016. Fossil capital: the rise of steam power and the roots of global warming. London: Verso.

Marijnen, E. and J. Verweijen. 2016. Selling green militarization: the discursive (re)production of militarized conservation in the Virunga National Park, Democratic Republic of the Congo. Geoforum 75: 274-285.

Markusson, N., F. Ginn, N. Singh Ghaleigh and V. Scott. 2014. 'In case of emergency press here': framing geoengineering as a response to dangerous climate change. Wiley Interdisciplinary Reviews: Climate Change 5(2): 281-290.

Massumi, B. 2015. Ontopower: war, powers, and the state of perception. Durham, NC: Duke University Press.

McCarthy, J. 2015. A socioecological fix to capitalist crisis and climate change? The possibilities and limits of renewable energy. Environment and Planning A 47(12): 2485-2502.

McCoy, A.W. 2017. In the shadows of the American Century: the rise and decline of US global power. Chicago: Haymarket Books.

McKibben, B. 2019. Money is the oxygen on which the fire of global warming burns. The New Yorker. [accessed October 1 2019]: https://www.newyorker.com/news/daily-comment/money-is-theoxygen-on-which-the-fire-of-global-warming-burns

McKinnon, C. 2019. The Panglossian politics of the geoclique. Critical Review of International Social and Political Philosophy DOI: 10.1080/13698230.2020.1694216

McLaren, D.P. 2018. Whose climate and whose ethics? Conceptions of justice in solar geoengineering modeling. Energy Research and Social Science 44: 209-221.

Mercure, J.F., H. Pollitt, J.E. Viñuales, N.R. Edwards, P.B. Holden, U. Chewpreecha, P. Salas, I. Sognnaes, A. Lam and F. Knobloch. 2018. Macroeconomic impact of stranded fossil fuel assets. Nature Climate Change 8(7): 588-593.

Miéville C. 2005. Between equal rights: a Marxist theory of international law. Chicago: Haymarket Books. Mitchell, T. 2009. Carbon democracy. Economy and Society 38(3): 399-432.

Momani, B. 2008. Gulf Cooperation Council oil exporters and the future of the dollar. New Political Economy 13(3): 293-314.

Moore, J.W. 2015. Capitalism in the Web of Life: ecology and the accumulation of capital. London: Verso.

Morrissey, J. 2016. US Central Command and liberal imperial reach: 'Shaping the Central Region for the 21st Century'. The Geographical Journal 182(1): 15-26. 
Murphy, T. 2010. Security challenges in the 21st century global commons. Yale Journal of International Affairs (5): 28-43.

Necheles, E., L. Burns, A. Chang and D.W. Keith. 2018. Funding for solar geoengineering from 2008 to 2018. Harvard Solar Geoengineering Research Program Blog. [accessed February 2 2020] https://geoengineering.environment.harvard.edu/blog/funding-solar-geoengineering

Nakano, J. and A. Stanley. 2018. Demystifying U.S.-China energy trade. Center for Strategic and International Studies. [accessed July 20 2019] https://www.csis.org/analysis/demystifying-us-chinaenergy-trade

National Research Council. 2015. Climate intervention: reflecting sunlight to cool Earth. Washington DC: National Academies Press.

Nightingale, P. and R. Cairns. 2014. The security implications of geoengineering: blame, imposed agreement and the security of critical infrastructure. [accessed April 12 2019] http://sro.sussex.ac.uk/id/eprint/52905/

Office of the Undersecretary of Defense for Acquisition and Sustainment. 2019. Report on effects of a changing climate to the Department of Defense. [accessed April 5 2020] https://media.defense.gov/2019/Jan/29/2002084200/-1/-1/1/CLIMATE-CHANGE-REPORT2019.PDF

O'Lear, S. and S. Dalby (eds.). 2015. Reframing climate change: constructing ecological geopolitics. London: Routledge.

Panitch, L. and S. Gindin. 2012. The making of global capitalism: the political economy of American Empire. London: Verso.

Parker, A. and P.J. Irvine. 2018. The risk of termination shock from solar geoengineering. Earth's Future 6(3): 456-467.

Parker, A., J.B. Horton and D.W. Keith. 2018. Stopping solar geoengineering through technical means: a preliminary assessment of counter-geoengineering. Earth's Future 6(8): 1058-1065.

Popular Science. 2005. How earth-scale geoengineering can save the planet. [accessed June 23 2019] https://www.vox.com/energy-and-environment/2018/1/23/16918280/trump-military-climatechange

Posen, B.R. 2003. Command of the commons: the military foundations of U.S.hegemony. International Security 28(1): 5-46.

Poulantzas, N. 2000. State, power, socialism. London: Verso.

Rabitz, F. 2016. Going rogue? Scenarios for unilateral geoengineering. Futures 84: 98-107.

Reynolds, J.L. 2019. The governance of solar geoengineering: managing climate change in the Anthropocene. Cambridge: Cambridge University Press.

Ricke, K., G. Morgan, J. Apt, D. Victor and S.J. Steinbruner. 2008. Unilateral geoengineering: non-technical briefing notes. Washington DC: Council of Foreign Relations.

Roberts, D. 2018. The problem with Trump leaving climate change to the military. Vox. [accessed May 5 2019] https://www.vox.com/energy-and-environment/2018/1/23/16918280/trump-military-climatechange

Robock, A. 2015. The CIA asked me about controlling the climate - this is why we should worry. The Guardian. [accessed June 10 2019] https://www.theguardian.com/commentisfree/2015/feb/17/ciacontrolling-climate-geoengineering-climate-change

Rosenberg J. 1994. The empire of civil society: a critique of the realist theory of international relations. London: Verso.

Schkoda, C.M., S.G. Cuan and E.D. McGrady. 2016. Examining long term climate related security risks through the use of gaming and scenario planning. Alexandria, VA: Center for Naval Analysis. [accessed June 21 2019] https://apps.dtic.mil/docs/citations/AD1047836 
Schwartz, P. and D. Randall. 2003. An abrupt climate change scenario and its implications for United States national security. Washington, D.C.: Department of Defense.

Schmitt, C. 2005. Political theology: four chapters on the concept of sovereignty. Chicago: University of Chicago Press.

Sillmann, J., T.M. Lenton, A. Levermann, K. Ott, M. Hulme, F. Benduhn and J.B. Horton. 2015. Climate emergencies do not justify engineering the climate. Nature Climate Change 5(4): 290-292.

Smith-Nonini, S. 2016. The role of corporate oil and energy debt in creating the neoliberal era. Economic Anthropology 3(1): 57-67.

Smith, W. and G. Wagner. 2018. Stratospheric aerosol injection tactics and costs in the first 15 years of deployment. Environmental Research Letters 13(12): 124001.

Spetalnick, M. 2020. U.S. offers to life Venezuela sanctions for power sharing deal, shifting policy. Reuters. [accessed April 5 2020]. https://www.reuters.com/article/us-venezuela-politics-usa-exclusive/u-soffers-to-lift-venezuela-sanctions-for-power-sharing-deal-shifting-policy-idUSKBN21I147

Spiro, D.E. 1999. The hidden hand of American hegemony: petrodollar recycling and international markets. Ithaca, NY: Cornell University Press.

Stokes, D. 2007. Blood for oil? Global capital, counter-insurgency and the dual logic of American energy security. Review of International Studies 33(2): 245-264.

Sugiyama, M., Y. Arino, T. Kosugi, A. Kurosawa and S. Watanabe. 2018. Next steps in geoengineering scenario research: limited deployment scenarios and beyond. Climate Policy 18(6): 681-689.

Surprise, K. 2018. Preempting the Second Contradiction: solar geoengineering as spatiotemporal fix. Annals of the American Association of Geographers 108(5): 1228-1244.

Surprise, K. 2019. Stratospheric imperialism: liberalism, (eco)modernization, and ideologies of solar geoengineering research. Environment and Planning E: Nature and Space https://doi.org/10.1177/2514848619844771.

Szerszynski, B., M. Kearnes, P. Macnaghten, R. Owen and J. Stilgoe. 2013. Why solar radiation management geoengineering and democracy won't mix. Environment and Planning A 45(12): 28092816.

Talberg, A., S. Thomas, P. Christoff and D. Karoly. 2018. How geoengineering scenarios frame assumptions and create expectations. Sustainability Science 13(4): 1093-1104.

Teller, E., L. Wood and R. Hyde. 1996. Global warming and ice ages I: prospects for physics-based modulation of global change. No. UCRL-JC-128715. Livermore, CA: Lawrence Livermore National Lab.

Tilmes, S., J.H. Richter, B. Kravitz, D.G. MacMartin, M.J. Mills, I.R. Simpson, A.S. Glanville, J.T. Fasullo, A.S. Phillips, J.F. Lamarque and J. Tribbia. 2018. CESM1 (WACCM) stratospheric aerosol Geoengineering Large Ensemble Project. Bulletin of the American Meteorological Society 99(11): 2361-2371.

Trumpbour, J. 1989. How Harvard rules: reason in the service of empire. Boston: South End Press.

U.S. Army. 2018. The U.S. Army in Multi-Domain Operations, 2028. [accessed August 18 2019] https://www.tradoc.army.mil/Portals/14/Documents/MDO/TP525-3-1_30Nov2018.pdf

Vasudevan, R. 2008. Finance, imperialism, and the hegemony of the dollar. Monthly Review 59(11): 35-50.

Victor, D., G. Morgan, F. Apt and J. Steinbruner. 2009. The geoengineering option: a last resort against global warming. Foreign Affairs 88(64).

Wagner G. and M.L. Weitzman. 2015. Climate shock: the economic consequences of a hotter planet. Princeton, NJ: Princeton University Press.

Wainwright, J. and G. Mann. 2018. Climate leviathan: a political theory of our planetary future. London: Verso.

Wood E.M. 1981. The separation of the economic and political in capitalism. New Left Review 127: 66-95. 